\title{
Assessment of Small Scale Methods for Quick Extraction of Genomic DNA from Leaf Tissue of Sugarcane
}

\author{
Sangeeta Srivastava* and Prashant Shekhar Gupta \\ Cytogenetics and Molecular Marker Laboratory, Division of Crop Improvement, Indian Institute of Sugarcane \\ Research, Lucknow-226 002, India
}

Received October 17, 2005; accepted May 12, 2006

\begin{abstract}
Summary Molecular studies to characterize genetic resources of sugarcane for use in breeding programmes require DNA extraction from several clones simultaneously so the DNA isolation procedures should be rapid, cheap, simple and easy to perform. Seven rapid protocols differing with respect to the composition of extraction buffers and DNA precipitation methods were compared to assess the quantity and quality of genomic DNA extracted from leaf material of different sugarcane genotypes. The DNA obtained was quantified and tested for quality, restriction digestion and PCR amplification using RAPD, SSR and ISSR primers. Two CTAB based methods essentially standardized over sugarcane were found most suitable for both large and small-scale isolation of DNA based on the purity, quality, quantity, applicability for PCR and stability upon storage. A third protocol also produced DNA of sufficient utility, however it requested further modifications.
\end{abstract}

Key words DNA isolation, Miniprep, Microsatellites, Polyphenols, Polysaccharide, Saccharum.

Cultivated sugarcane varieties belong to the genus Saccharum, which is very complex heterozygous polyploid characterized by high chromosome numbers. The basic chromosome number of genus Saccharum is debatable and no putative diploid donors have been found. Cultivated sugarcane varieties are derivatives of a few interspecific crosses performed early in this century (Heinz 1987) and no efforts were made in the past to evaluate new gene resources for introgressive breeding hence a considerable portion of available genetic diversity remains to be exploited. Phylogenetic studies pertaining to molecular systematics may therefore be very useful to rationalize the use of genetic resources in breeding through marker-assisted selection for economic traits. Such studies usually entail screening of a large number of progeny clones and call for rapid, simple and easy to perform DNA isolation procedures for initial grinding.

Sugarcane tissues contain high levels of polysaccharides and polyphenolic compounds, which present a major contamination problem in the purification of sugarcane DNA. Several protocols have been described for such plants e.g. extaction of nuclei (Hamilton et al. 1972), DNA extraction and purification by cesium chloride (Murray and Thompson 1980), a rapid DNA extraction method for sugarcane (Honeycutt et al. 1992, Aljanabi et al. 1999). Most of the protocols involve either the use of liquid nitrogen for initial grinding which is often difficult to obtain, or use expensive chemicals. A number of small-scale protocols have also appeared in the literature recently that allow the recovery of small amount of DNA of sufficient purity for PCR amplification. To assess the comparative performance of these protocols on sugarcane, a preliminary study was conducted to evaluate several small-scale protocols especially of graminaceous crops. Based on the results, 7 quick methods of genomic DNA extraction from plants were selected which included monocots like maize, rice, sugarcane and dicot crops like apple, strawberry, lettuce. Total genomic DNA extracted from leaf material of different sugarcane genotypes of subtropical India using these 7 protocols, was

\footnotetext{
* Corresponding author, e-mail: sangeeta_anil@sify.com
} 
Table 1. Efficiency of different methods of rapid DNA extraction

\begin{tabular}{|c|c|c|c|c|}
\hline $\begin{array}{l}\text { S. } \\
\text { No. }\end{array}$ & $\begin{array}{l}\text { Method } \\
\text { and } \\
\text { year }\end{array}$ & $\begin{array}{l}\text { Applicable } \\
\text { on }\end{array}$ & $\begin{array}{c}\text { Tris EDTA } \\
\text { extraction buffer } \\
\text { (pH 8.0) containing }\end{array}$ & $\begin{array}{l}\text { Precipitation } \\
\text { by }\end{array}$ \\
\hline 1 & $\begin{array}{l}\text { Edward et al. } \\
\text { (1991) }\end{array}$ & Plants & SDS & Isopropanol \\
\hline 2 & $\begin{array}{l}\text { Cheung et al. } \\
\text { (1993) }\end{array}$ & $\begin{array}{l}\text { Plant, insect, } \\
\text { animals }\end{array}$ & Sarcosyl & $\begin{array}{l}\text { Ammonium acetate } \\
\text { and isopropanol }\end{array}$ \\
\hline 3 & $\begin{array}{l}\text { Oard and Dronovalli } \\
\text { (1992) }\end{array}$ & Maize and rice & 2-mercaptoethanol & $\begin{array}{c}\text { Ammonium acetate } \\
\text { and ethanol }\end{array}$ \\
\hline 4 & $\begin{array}{l}\text { Honeycutt et al. } \\
\text { (1992) }\end{array}$ & Sugarcane & $\begin{array}{l}\text { 2-mercaptoethanol, PEG, } \\
\text { sucrose and spermidine }\end{array}$ & Isopropanol \\
\hline 5 & $\begin{array}{l}\text { Aljanabi et al. } \\
\text { (1999) }\end{array}$ & $\begin{array}{c}\text { Sugarcane, lettuce, } \\
\text { strawberry }\end{array}$ & $\begin{array}{c}\text { N-lauroyl-sarcosine, } \\
\text { CTAB, PVP and } \\
\text { sodium sulfite }\end{array}$ & $\begin{array}{l}\text { Isopropanol and } \\
\mathrm{NaCl}\end{array}$ \\
\hline 6 & $\begin{array}{l}\text { Dilworth and Frey } \\
(2000)\end{array}$ & Apple leaves & $\begin{array}{l}\text { Tween } 20 \text { and } \\
\text { proteinase } \mathrm{K}\end{array}$ & No precipitation \\
\hline 7 & $\begin{array}{l}\text { Ikeda et al. } \\
\text { (2001) }\end{array}$ & Rice & - & No precipitation \\
\hline
\end{tabular}

* Represents average of pooled data of 8 sugarcane genotypes.

evaluated qualitatively as well as quantitatively to compare their performance for PCR based amplification.

Materials and methods

\section{DNA extraction}

Fresh green leaves of 8 elite subtropical Indian sugarcane genotypes (Saccharum species hybrids) viz. CoLk 9412, CoLk 9616, CoLk 8102, CoLk 91238, CoLk 91239, CoLk 9617, CoJ 64 and CoJ 96192 were collected from the sugarcane fields of Indian Institute of Sugarcane Research, Lucknow, India. Leaves were washed with sterile water; cut into small pieces with sterilized blades, weighed about $5-10 \mathrm{~g}$ and placed into precooled $\left(-20^{\circ} \mathrm{C}\right)$ mortar.

Seven rapid methods of DNA extraction from young leaf tissues of different crops including sugarcane were attempted (Table 1). Precipitated DNA was washed with $70 \%$ ethanol and dried pellets of DNA were resuspended in TE (Tris-EDTA) buffer.

\section{Comparative efficiency of different protocols}

Quality and quantity For quantity and purity of genomic DNA, UV spectrophotometer (Beckmann) absorbance readings of DNA samples were used. Total yield of DNA in $\mu \mathrm{g} / \mathrm{g}$ fresh material and quality of DNA (Ratio of O.D. $A_{260} / A_{280}$ ) were calculated.

\section{Restriction digestion}

Genomic DNA from each method was digested with HindIII (M/S Bangalore Genei, India) and was run on $1 \%$ agarose gel along with $5-10 \mu \mathrm{g}$ of uncut DNA.

\section{PCR amplification}

The extracted DNA was amplified in MJ Research PTC 200 Thermal Cycler to find out their suitability and applicability for PCR based markers like RAPD, microsatellite and ISSR. Two random decamer primers, 2 pairs of forward and reverse flanking sequences of microsatellites and 2 Inter Simple Sequence Repeats were used for amplification initiation (Table 2). The amplified prod- 
on yield and purity of DNA in Saccharum species hybrids

\begin{tabular}{cccc}
\hline \hline \multicolumn{2}{c}{ Purity of DNA* } & & \multicolumn{2}{c}{ Amount of DNA $(\mu \mathrm{g} / \mathrm{g} \text { fresh tissue })^{*}$} \\
\hline Mean \pm S.E. & Range & Mean \pm S.E. & Range \\
\hline $1.32 \pm 0.07$ & $0.96-1.54$ & $608.57 \pm 19.65$ & $524.88-676.88$ \\
$1.68 \pm 0.04$ & $1.45-1.81$ & $150.31 \pm 10.27$ & $121.70-188.72$ \\
$1.58 \pm 0.02$ & $1.50-1.67$ & $111.02 \pm 3.54$ & $98.84-131.50$ \\
$1.84 \pm 0.02$ & $1.76-1.89$ & $260.30 \pm 11.18$ & $204.07-293.43$ \\
$1.85 \pm 0.03$ & $1.80-1.90$ & $268.68 \pm 9.18$ & $221.09-295.11$ \\
$1.26 \pm 0.12$ & $1.12-1.44$ & & $99.54-135.16$ \\
$1.25 \pm 0.06$ & $1.17-1.32$ & $115.16 \pm 4.16$ & $98.66-124.38$ \\
\hline
\end{tabular}

ucts of RAPD were separated by electrophoresis in a $2.0 \%$ agarose gel in $1 \times$ TBE (Tris-EDTA borate) buffer in SubCell GT electrophoresis unit of Bio-Rad (Bio-Rad Laboratories, Inc. Hercules, $\mathrm{CA}$ ) and stained with $0.5 \mu \mathrm{g} / \mathrm{ml}$ of ethidium bromide (EtBr) to determine the RAPD profile. Amplified SSR and ISSR products were resolved on $8 \%$ polyacrylamide gels run in mini Protean III unit of BioRad and detected with ethidium bromide and silver staining respectively. The gels were photographed with a CCD camera attached to AlphaImager ${ }^{\mathrm{TM}}$ gel documentation system (Alpha Innotech Corporation, SanLeandro, CA) and stored in 3\% acetic acid.

\section{Results}

The comparison of 7 rapid procedures of genomic DNA isolation, from leaf tissues of 8 cultivated sugarcane genotypes of subtropical India has shown significant difference in the yield and quality of extracted DNA (Table 1). The methods were adapted to use the minimum of specialized equipments and steps and at least 10 replicate samples were tested for each genotype.

\section{Yield of extracted DNA}

DNA yield of 8 genotyes through these 7 methods (Table 1) was estimated by UV spectrophotometer readings of DNA samples at 260 and $280 \mathrm{~nm}$. Total yield of DNA was calculated as $\mu \mathrm{g} / \mathrm{g}$ fresh material. ANOVA for DNA amount indicated significant difference of methods of extraction on DNA yield at $\mathrm{P}=1 \%$ as well as $0.1 \%$ level of significance. The average yield of DNA ranged from $109.99 \mu \mathrm{g} / \mathrm{g}$ in the method of Ikeda et al. (2001) to $608.57 \mu \mathrm{g} / \mathrm{g}$ fresh tissue in the method of Edward et al. (1991). DNA yields in the range 20-100 $\mu \mathrm{g}$ per gram of fresh material should be sufficient for restriction analysis and more than sufficient for PCR, provided they have $A_{260} / A_{280}$ ratios in the range of 1.65 to 1.80 (Marechal-Drouard and Guillemant 1995). In the third, sixth and seventh methods (Oard and Dronovalli 1992, Dilworth and Frey 2000, Ikeda et al. 2001, respectively) the yield of DNA was very low (111.02, 115.16 and $109.99 \mu \mathrm{g} / \mathrm{g}$ fresh tissue respectively), therefore these methods were found inappropriate in sugarcane. 


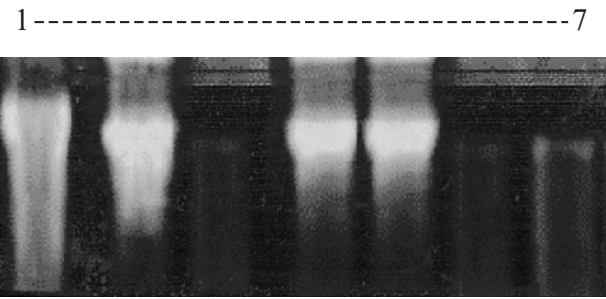

(a)
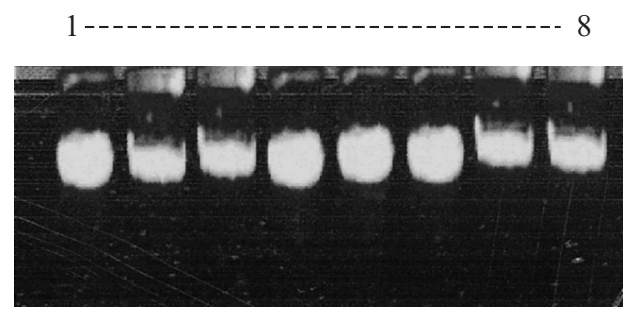

(c)
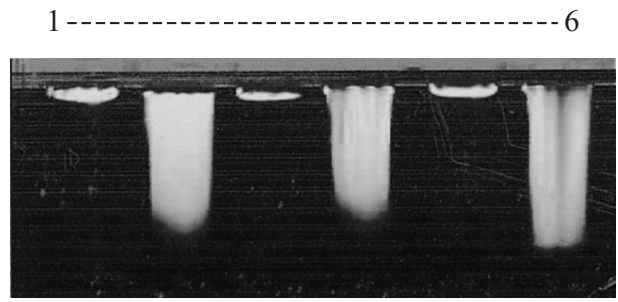

(b)
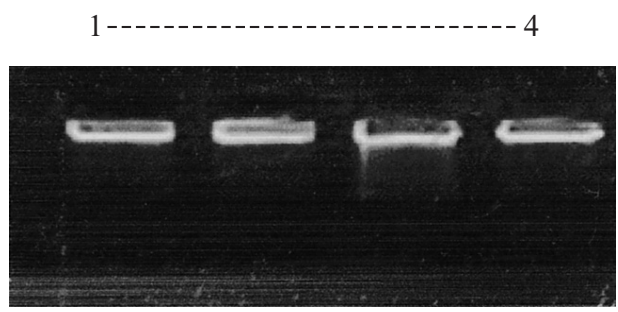

(d)

Fig. 1. Comparative profile of total genomic DNA of sugarcane, maize and rice. (a) Genomic DNA of sugarcane genotype CoLk 8102 from 7 different methods (lane 1-7: method 1-7)*. (b) Undigested (lane 1, 3 and 5) and HindIII restriction digested (lane 2, 4 and 6) pattern of genomic DNA of CoLk 8102 by second (lane 1,2), fourth (lane 3,4) and fifth (lane 5,6) methods of DNA isolation. (c) Genomic DNA of 8 sugarcane genotypes with method 5 (genotypes in lane 1-8 are CoLk 9412, CoLk 9616, CoLk 8102, CoLk 91238, CoLk 91239, CoLk 9617, CoJ 64 and CoJ 96192). (d) Genomic DNA of maize and rice (lane 1 and 2-maize with methods 4 and 5, and lane 3 and 4-rice with methods 4 and 5 respectively). * Sequence of methods 1 to 7 as given in Table 1 .

\section{DNA quality}

DNA quality of 8 genotypes through 7 methods was estimated by measuring the UV absorbance ratio $A_{260} / A_{280}$, the mean value of which ranged from 1.25 (method-7) to 1.84 (method-5). ANOVA for purity of DNA also shows significant difference among the methods at $1 \%$ as well as $0.1 \%$ level of significance. The purity of extracted DNA in first (Edward et al. 1991), third (Oard and Dronovalli 1992), sixth (Dilworth and Frey 2000) and seventh (Ikeda et al. 2001) methods (average 1.32, 1.58, 1.26 and 1.25, respectively) was not suitable for PCR amplification because DNA samples with $A_{260} / A_{280}$ ratios in the range of 1.65 to 1.80 are usually suitable for molecular techniques like RFLP analysis, PCR amplification, nucleotide analysis by HPLC and detection of hyper modified nucleotides (adducts) by post labeling with ${ }^{32} \mathrm{P} 80$ (Marechal-Drouard and Guillemant 1995).

To further check the quality of DNA, $2 \mu \mathrm{g}$ of genomic DNA of each sample from all the 7 methods were run on $1.0 \%$ agarose gel. The results showed that the bands were most sharp and distinct in the methods- 4 and -5 of Honeycutt et al. and Aljanabi et al., respectively (Fig. 1a). There was neither RNA contamination nor any sign of degraded DNA in all the samples of fourth and fifth CTAB methods (Honeycutt et al. 1992, Aljanabi et al. 1999). Therefore, there was no requirement of RNAse treatment of DNA sample. It seems that RNA is degraded in these methods during the process of extraction. After studying the comparative response of different Saccharum spp. hybrids to the 7 methods of genomic DNA extraction (Table 1) and bands on agarose gel electrophoresis, method-4 of Honeycutt et al. (1992) and method-5 of Aljanabi et al. (1999) seem most suitable for DNA isolation in sugarcane as they yielded DNA of sufficient purity and quantity (Table 1). 


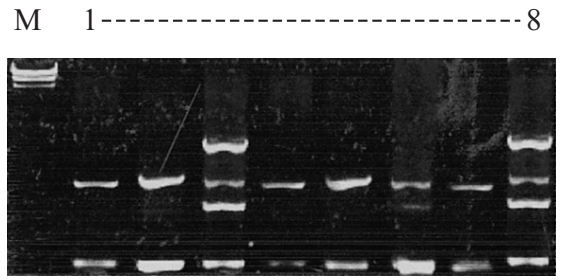

(a)

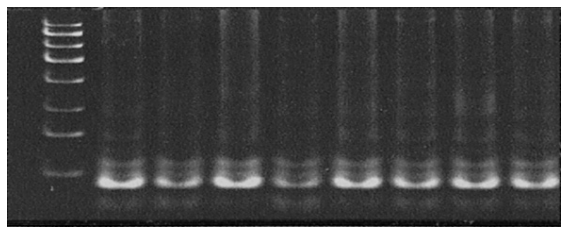

(c)

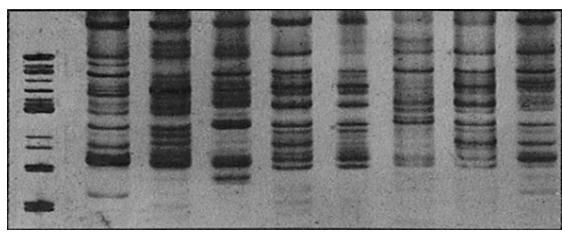

(e)

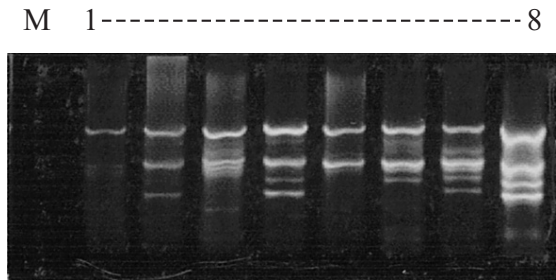

(b)

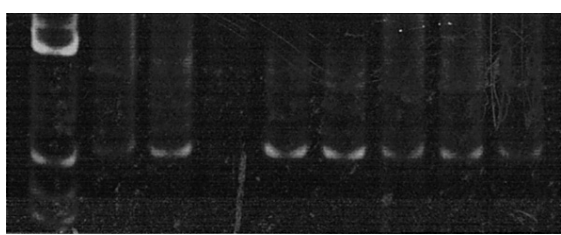

(d)

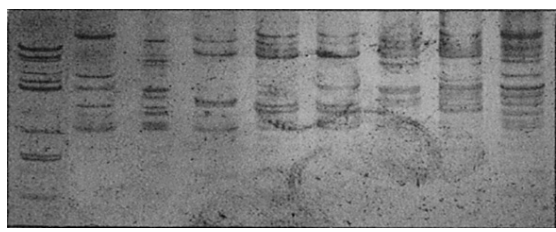

(f)

Fig. 2. Amplified band pattern of 3 kinds of PCR based markers with total DNA obtained from methods 4 and 5 (genotypes in lane 1-8 are CoLk 9412, CoLk 9616, CoLk 8102, CoLk 91238, CoLk 91239, CoLk 9617, CoJ 64 and CoJ 96192). a, c, e, PCR amplified products using DNA template from method-4 and random primer OPC-16, SSR primer mSSCIR57 and ISSR primer ISSR 6 respectively; b, d, f, PCR amplified products using DNA template from method-5 and random primer OPA-16, SSR primer mSSCIR76 and ISSR primer ISSR 1 respectively; M, marker.

\section{Restriction digestion of total DNA}

Isolated DNA from 3 methods (second, fourth and fifth), which showed sufficient purity was digested with HindIII restriction endonuclease and separated on 1\% agarose gel to compare the quality of genomic DNA. Approximately 5-10 $\mu \mathrm{g}$ of DNA was used in the digestion reactions. The relative intensities of uncut and HindIII digested genomic DNA in different genotypes are depicted in Fig. $1 \mathrm{~b}$ which substantiate the DNA purity values based on UV absorbance ratio.

\section{PCR based amplification using different primers}

As DNA quality was being tested for molecular applications (Dellaporta et al. 1983), the genomic DNA from these 7 methods was subjected to PCR amplification using 2 primers each of random decamers, SSR and ISSR and it was observed that DNA from second, fourth and fifth methods was successfully amplified. The PCR based application worked well with DNA from these 3 methods and resulted in comparable amplification products, however, DNA bands produced from methods-4 and -5 (Honeycutt et al. 1992, Aljanabi et al. 1999) were more sharp and distinct. A representative photograph of each primer is given in Fig. 2.

\section{Discussion}

At a glance to the Table 1, one can easily deduce that the methods-6 and 7 (Dilworth and Frey 
Table 2. Primer sequences of 3 types of PCR based markers used to evaluate the amplification of genomic DNA

\begin{tabular}{cccc}
\hline \hline Marker & Primer & Primer sequences $\left(5^{\prime}-3^{\prime}\right)$ & Size $^{\mathrm{a}}(\mathrm{bp})$ \\
\hline \multirow{2}{*}{ RAPD $^{\mathrm{b}}$} & OPC-16 & CAC ACT CCA G & - \\
& OPA-16 & AGC CAG CGA A & - \\
SSR $^{\mathrm{c}}$ & mSSCIR57 & CTTCTTCTTCTCCTGGTAA & 226 \\
& mSSCIR76 & TGATCGGTAATATAATGGC & 325 \\
& GCGAACCAAGGAGAAGCA & - \\
ISSR & ISSR 6 & TCCACCGAGTTCCCATTG & - \\
& ISSR 1 & $(\mathrm{CA})_{6} \mathrm{AG}$ & - \\
\hline
\end{tabular}

${ }^{a}$ Expected size of amplified product. RAPD and ISSR size are not shown because of the multiple bands. ${ }^{\mathrm{b}}$ Purchased from M/S Operon Technologies, USA. ${ }^{\mathrm{c}}$ Primer flanking sequences to amplify the microsatellite region provided by Drs. A. D’Hont and F. Paulet, CIRAD (Montpellier), France.

2000, Ikeda et al. 2001, respectively) have entirely failed in case of sugarcane as neither the yield, or the purity of DNA is anywhere near sufficient. Ostensibly, the fact that sugarcane is enriched with polyphenols and polysaccharides has played a role here and extraction buffers devoid of any adjuvant to counteract polyphenols and polysaccharides failed to deliver the goods. The DNA obtained through the first (Edward et al. 1991) and second (Cheung et al. 1993) method was of brown colour in appearance, which indicated the presence of polyphenols. Likewise in method-1, although the yield was very good, the purity of DNA was least (0.96-1.54) and its use was limited by its brown colour indicating thereby, the presence of polyphenolic and polysaccharide compounds, however, method-2 resulted in DNA of relatively high purity and considerably good yield. Polysaccharide removal by the use of glycoside hydrolases followed by phenol/chloroform extraction has been found to yield high quality DNA preparations (Rether et al. 1993). Length of incubation and subsequent purification steps make this approach less suitable for rapid extraction. Other methods of polysaccharide removal such as purification through RPC-5 resin (Do and Adams 1991) or use of DEAE cellulose (Marechal-Drouard and Guillemant 1995) may also be adapted. High salt-ethanol precipitations have also been suggested (Fang et al. 1992).

Method-2 in fact already uses a high salt buffer, and DNA obtained through this method is free of polysaccharides, however, it needs removal of polyphenolic compounds. In their oxidized forms, polyphenols covalently bind to DNA giving it a brown colour and making it useless for most research applications (Fang et al. 1992). To inhibit the interaction of genomic DNA with oxidized polyphenols, compounds that adsorb polyphenols or prevent oxidation reactions are recommended for use with this method.

An obvious approach to avoid polyphenol contamination of the final DNA preparation would be to isolate nuclei prior to lysis. Kattermann and Shattuck (1983) successfully isolated DNA from Gossypium spp. containing large amount of polyphenols by isolating nuclei in a buffer of sodium citrate and glucose. Proteinase K in the extraction buffer of method-6, seems to inhibit PCR amplification and its denaturation is essential. Complete digestion with restriction endonucleases of second, fourth and fifth methods (Fig. 1b) and successful amplification in PCR using RAPD primers (Fig. 2a, b), SSR primers (Fig. 2c, d) and ISSR primers (Fig. 2e, f) of DNA from fourth and fifth methods indicate the absence of polysaccharides and purity of DNA (Do and Adams 1991).

After studying the comparative response of different Saccharum spp. hybrids (Table 1), bands on agarose gels (Fig. 1c) and applicability of PCR based techniques (Fig. 2), the CTAB methods given by Honeycutt et al. (1992) and Aljanabi et al. (1999) were found most suitable for DNA isolation as they yielded DNA of sufficient purity and quantity from all the sugarcane genotypes under 
study. The extracted DNA could be easily amplified through PCR using different primers for RAPD, simple sequence length repeats and inter simple sequence repeats. These methods also proved successful when applied to maize and rice (Fig. 1d). The methods are suitable for both large and small-scale isolations. They also yield DNA suitable for PCR related techniques as well. The method of extraction given by Aljanabi et al. (1999) proved to be most successful in our conditions probably due to several advantages it had over the others, e.g. avoiding use of liquid nitrogen and RNA treatment, use of PVP and sodium sulphite to adsorb and bind polyphenols besides being quick and inexpensive. The only drawback of method-4 (Honeycutt et al. 1992) is that the process is lengthy due to triple extraction through wash buffer, thereby, limiting the number of samples that can be processed each day. Besides, the method requires the use of meristematic portion and it is sometimes difficult to get meristems, if the plant population is low. Since method-2 also showed good level of purity as well as yield of DNA (but of brown colour, due to polyphenolic compounds), certain modifications might be tried to prevent the formation of polyphenols. The extracted DNA was stable upon storage in methods of Honeycutt et al. (1992) and Aljanabi et al. (1999), and also in method-2 provided some adjuvant like PVP were added during extraction in method-2. Modification of these methods to evolve a rapid and easy protocol of DNA extraction from various plant parts of sugarcane with or without utilizing liquid nitrogen to suite one's conditions may also be tried.

\section{Acknowledgements}

This work was supported by grants of ICAR Young Scientist award ad-hoc scheme of ICAR, New Delhi, to the first author. The authors are highly grateful to the Director, IISR, Lucknow, for providing the necessary facilities to carry out the experiments. Financial assistance in the form of Research Associate ship to the second author (PSG) is gratefully acknowledged. The authors are especially thankful to Drs. A. D'Hont and F. Paulet, CIRAD (Montpellier), France for providing primer sequences of sugarcane micro satellites.

\section{References}

Aljanabi, S. M., Forget, L. and Dookun, A. 1999. An improved and rapid protocol for the isolation of polysaccharide- and polyphenol-free sugarcane DNA. Plant Mol. Biol. Reptr. 17: 1-8.

Cheung, W. Y., Hubet, N. and Landry, B. S. 1993. A simple and rapid DNA micro extraction method for plant, animal and insect suitable for RAPD and other PCR analyses. PCR Meths. Applics. 3: 69-70.

Dellaporta, S. L., Wood, J. and Hicks, J. B. 1983. A plant DNA minipreparation: version II. Plant Mol. Biol. Reptr. 1: 19-21.

Dilworth, E. and Frey, J. E. 2000. A rapid method for high throughput DNA extraction from plant material for PCR amplification. Plant Mol. Biol. Reptr. 18: 61-64.

Do, N. and Adams, R. P. 1991. A simple technique for removing plant polysaccharide contaminants from DNA. BioTechniques 10: $162-166$.

Edwards, K., Johnstone, C. and Thompson, C. 1991. A simple and rapid method for the preparation of plant genomic DNA for PCR analysis. Nucl. Acids Res. 19: 1349.

Fang, G., Hammer, S. and Grumet, R. 1992. A quick and inexpensive method for removing polysaccharides from plant genomic DNA. BioTechniques 13: 52-55.

Hamilton, R. H., Künsch, U. and Temperli, A. 1972. Simple rapid procedures for isolation of tobacco leaf nuclei. Analyt. Biochem. 49: 48-57.

Heinz, D. J. 1987. Sugarcane Improvement: current productivities and future opportunities. In: Copersucar Int. Sugarcane Breed. Workshop, Copersucar, Sao Paulo, pp. 57-70.

Honeycutt, R. J., Sobral, B. W. S., Kiem, P. and Irvine, J. 1992. A rapid DNA extraction method for sugarcane and its relatives. Plant Mol. Biol. Reptr. 10: 66-72.

Ikeda, N., Bautista, S., Yamada, T., Kamijima, O. and Ishii, T. 2001. Ultra-simple DNA extraction method for marker-assisted selection using microsatellite markers in rice. Plant Mol. Biol. Reptr. 19: 27-32. 
Katterman, F. R. H. and Shattuck, V. L. 1983. An effective method of DNA isolation from the mature leaves of Gossypium species that contain large amounts of phenolic terpenoids and tannins. Preparative Biochem. 13: 347-359.

Mare'chal-Drouard, L. and Guillemaut, P. 1995. A powerful but simple technique to prepare polysaccharide-free DNA quickly and without phenol extraction. Plant Mol. Biol. Reptr. 15: 26-30.

Murray, M. G. and Thompson, W. F. 1980. Rapid isolation of high molecular weight plant DNA. Nucleic Acids Res. 8: 4321-4325.

Oard, J. H. and Dronovalli, S. 1992. Rapid isolation of rice and maize DNA for analysis by random primer PCR. Plant Mol. Biol. Reptr. 10: 236-241.

Rether, B., Delmas, G. and Laouedj, A. 1993. Isolation of polysaccharide-free DNA from plants. Plant Mol. Biol. Reptr. 11: 333-337. 